\title{
Determination of the content of selected elements in medieval waterlogged oak wood from the Lednica Lake - a case study
}

\author{
Magdalena Broda $^{1}$ (D) $\cdot$ Marcin Frankowski $^{2}$
}

Received: 31 January 2017 / Accepted: 16 August 2017 / Published online: 26 August 2017

(C) The Author(s) 2017. This article is an open access publication

\begin{abstract}
The content of selected elements: Al, B, Ba, Ca, $\mathrm{Cd}, \mathrm{Co}, \mathrm{Cr}, \mathrm{Cu}, \mathrm{Fe}, \mathrm{K}, \mathrm{Li}, \mathrm{Mg}, \mathrm{Mn}, \mathrm{Mo}, \mathrm{Na}, \mathrm{Ni}, \mathrm{P}, \mathrm{Pb}, \mathrm{Sb}$, $\mathrm{Si}, \mathrm{Ti}, \mathrm{V}$ and $\mathrm{Zn}$ was determined in archaeological waterlogged oak wood from the Lednica Lake by using the inductively coupled plasma optical emission spectrometry (ICPOES) method. The concentration of metals (especially heavy metals) in wood is typically specified to characterise this material and evaluate the possibility to use it for industrial purposes. In case of waterlogged archaeological wood intended for further research on new methods of conservation, such an analysis is important for other reasons. As it has been confirmed by numerous conservators and researchers, the presence of metal compounds is a serious problem not only due to their destructive influence on wood tissue but also from a conservation/re-conservation perspective. Metal-containing chemicals may influence conservation treatments by reacting with substances used for wood conservation and causing irreversible damage to wooden objects. Therefore, while developing new solutions for wood conservation, a broad knowledge not only on the state of wood preservation and deterioration but also on interacting chemical factors is required. The results of the research clearly show that content of minerals in
\end{abstract}

Responsible editor: Michel Sablier

Magdalena Broda

mbroda@up.poznan.pl

$\triangle$ Marcin Frankowski

marcin.frankowski@amu.edu.pl

1 Institute of Wood Chemical Technology, Faculty of Wood Technology, Poznań University of Life Sciences, Wojska Polskiego 38/42, 60-637 Poznań, Poland

2 Department of Water and Soil Analysis, Faculty of Chemistry, Adam Mickiewicz University in Poznań, Umultowska 89 b, 61-614 Poznań, Poland waterlogged wood excavated from the bottom of the Lednica Lake considerably exceeded the average percentage of these elements in contemporary wood, which is associated with the mineralisation process. Moreover, variability in metal content was observed between waterlogged and contemporary wood. In waterlogged wood, the highest concentrations of $\mathrm{Ca}, \mathrm{Fe}$, $\mathrm{Mg}$ and $\mathrm{P}$ were observed, while in contemporary oak wood the predominant concentrations of $\mathrm{K}, \mathrm{Ca}, \mathrm{Mn}$ and $\mathrm{Si}$ were determined. Statistical analysis showed the variability in content of elements between different archaeological wood zones and contemporary wood. On the basis of the results obtained, it could be concluded that the studied waterlogged wood acted as an adsorbent of elements from water and sediments. High content of metal ions can be an impediment in developing new formulations for conservation, while using this wood as an experimental material. Therefore, while planning to use new chemicals as conservation agents, the possible interactions between chemicals and metals must be taken into consideration.

Keywords Waterlogged archaeological wood · Inorganic compounds $\cdot$ IPC-OES $\cdot$ Oak $\cdot$ Submerging environment

\section{Introduction}

Wood as a natural lignocellulosic material is effectively decomposed by microorganisms within the carbon cycle in nature. This process is rather fast and usually takes from a few years to several decades. However, wooden objects buried in in the ground or water reservoirs deteriorate very slowly. Due to an extremely low oxygen concentration or even anaerobic conditions in waterlogged terrestrial or aquatic environments, only erosion bacteria or some soft rot fungi are able to decay wood. Slow microbial degradation results in 
decomposition of cellulose, which is the main component of the secondary cell wall, whereas the lignin-rich middle lamellae remain outwardly intact. The coherent network of unaffected middle lamellae and water, which fills out the degraded cell walls and cell lumina, allow waterlogged decayed wood to keep its physical integrity and the well-preserved appearance as long as it remains wet. Nonetheless, if the wood is allowed to dry, it shrinks, cracks and disintegrates as a result of the impact of the capillary forces upon drying (Björdal et al. 1999; Blanchette 2010; Kim et al. 1996). Once excavated from water reservoirs or from the ground, archaeological waterlogged wooden objects therefore require an immediate treatment to stabilise the degraded wood tissue and protect it from irreversible deformation or destruction.

Typically, chemical and physical characteristics of wood are measured to evaluate its condition and understand mechanisms of degradation. Such a knowledge is essential to design the best possible conservation treatment in order to keep the integrity and dimensions of wooden artefacts. Moreover, it is helpful to suggest the most appropriate environmental conditions for long-term storage or exhibition of waterlogged objects without endangering their safety (Blanchette et al. 1994; Florian 1990). Chemical characterisation of such material is usually limited to qualitative and quantitative analysis of the main organic wood components (cellulose, hemicellulose, lignin) which most commonly deteriorate due to selective enzymatic hydrolysis by anaerobic microorganisms (Bardet et al. 2009; Björdal 2012; Browning 1967; Łucejko et al. 2015; Pizzo et al. 2015; Salanti et al. 2010). However, also abiotic factors, including temperature, pressure and various environmental parameters, can be responsible for wood degradation. Although relatively little is known about the contribution of these processes to wood deterioration due to the long period of time required for evident signs of degradation as well as the masking effect of microbial activity (Blanchette et al. 1994), their influence should not be marginalised. Particularly, the damaging impact of water with its acid-base and oxidisingreducing properties resulting from the presence of metal compounds should not be underestimated.

The presence of some metal ions in wood is considered to have a preservation effect (Blanchette et al. 1994). For example, copper- or boron-based wood preservatives have been widely used for many years to protect timbers exposed outside (Hingston et al. 2001; Obanda et al. 2008). Nonetheless, it has also been repeatedly confirmed that other metal ions can contribute to wood degradation. The products of metal corrosion can extensively degrade wood tissue and cause considerable alterations of a cell wall, including formation of metal pseudomorphs - the replicas of wood cell wall (Baker 1974; Blanchette and Simpson 1992; Marian and Wissing 1960; Parameswaran and Borgin 1980). Problems with metal compounds contributing to archaeological wood degradation are well documented in a number of case studies on shipwrecks such as the Vasa, Mary Rose, Batavia and Oseberg findsViking ships (Braovac et al. 2016; Fors and Sandström 2006; Preston et al. 2014). Especially the destructive effect of iron on archaeological wood is well known and confirmed by many researchers (Almkvist et al. 2013; Fors et al. 2012; Huisman et al. 2008; Preston et al. 2014). High iron contents are mainly associated with shipwrecks due to frequent occurrence of iron fastenings or other objects connected with or found near such wooden artefacts. In waterlogged wood, the most common are diverse iron (III) hydroxides and oxides, iron (II) salts as well as reduced sulphur compounds containing iron, such as pyrite and pyrrhotite. Their presence results in mechanical or chemical degradation of wood tissue. Mechanical damage occurs during drying of the wooden object without protective treatment as a result of iron (and other inorganic compounds) accumulating in the surface region. Chemical degradation is rather a postconservation problem. It proceeds due to oxidation of reduced sulphur species, probably catalysed by iron ions, which generates sulphuric acid that can lead to hydrolysis of wood polysaccharides (Blanchette et al. 1991; Parameswaran 1981; Sandström et al. 2002; Sandström et al. 2005). Coming from the corroded metal objects accompanying wooden artefacts, ionic iron and copper compounds can migrate into the wood and promote wood degradation via radical Fenton reactions (strongly oxidising hydroxy radicals are formed, which can abstract e.g. hydrogen atoms from cellulose or hemicellulose) (Braovac et al. 2016; Henry 2003). Moreover, iron and other metal compounds $(\mathrm{Co}, \mathrm{Mn}, \mathrm{Cu}, \mathrm{Ni})$ can catalyse a variety of different chemical reactions and thus contribute to abiotic wood degradation (Almkvist et al. 2013; Baker 1974; Blanchette and Simpson 1992; Keepax 1975; Sandström et al. 2004).

In waterlogged wood preservation, the presence of metal compounds is a serious problem not only due to their destructive influence on wood tissue but also from a conservation/reconservation perspective. Metal-containing chemicals in wood may influence conservation treatments. Oxidative reactions involving metal compounds cause depolymerisation of both wood components and preservation agents (e.g. polyethylene glycol). As a result, various low molecular organic acids like glycolic, formic or oxalic are generated, causing further wood degradation (Almkvist et al. 2013). Metal compounds may be located inside the cell wall or precipitated in specific regions of the wood cell, such as bordered pit membranes, where they could influence permeability of the wood and interfere with the conservation process (Florian 1990). They can also interact with tannins in the wood and form insoluble complexes when exposed to oxygen, blocking the wood microstructure for penetration of conservation substances (Sandström et al. 2004). Therefore, the conservator should know precisely the total chemical composition of a wooden object which is to be preserved as well as the location of inorganic substances to consider removing or inactivation of hindering compounds in wood before conservation. 
Concentration of metals (especially heavy metals) in wood is typically determined to characterise this material and evaluate the possibility to use it for industrial purposes, e.g. for combustion processes as an ecological energy source or for paper production. It is also useful to observe changes in wood caused by biotic (fungal or insect attack) and abiotic factors (like the influence of environmental contamination on the accumulation of metals in wood). Such a comprehensive analysis of archaeological waterlogged wood has never been done before.

The aim of the research was to evaluate the content of selected metals in archaeological waterlogged oak wood and determine their distribution in respective wood layers. Intended for further study on new methods of wood conservation, this unique wooden material was excavated from the Lednica Lake in the Wielkopolska Region, Poland - one of the most thoroughly explored underwater archaeological sites. The wooden pile was the structural element of the early medieval "Poznań" bridge (Fig. 1). As one of the biggest wooden bridges in Europe at that time, it shows the independent technology of the Slavs from the turn of the tenth and eleventh centuries. The "Poznań" bridge connected the shore of the Ostrów Lednicki island with the road leading into the Poznań city. On the island, there was one of the most prominent political, cultural and religious centres of the monarchy of the first Piasts dynasty during the reign of Mieszko I and his son Bolesław I the Brave, the first King of Poland. Along with wooden remains of the bridge, thousands of early medieval material culture artefacts were found nearby, including the largest unique collection of Slavic militaria (Kola and Wilke 2014). Increased knowledge on the state of archaeological wood preservation, its chemical composition as well as of wood deterioration and interacting chemical, environmental and physical factors is essential for continuing the development of new, improved methods for archaeological waterlogged wood conservation and display.

\section{Materials and methods}

\section{Samples}

The unique archaeological wood material selected for this study was a waterlogged oak (Quercus robur) pile. Situated at the bottom of the lake, between other remains of the bridge in a pass with a width of approximately $20 \mathrm{~m}$, the wooden pile was almost completely buried under a layer of mud under anoxic conditions, about $11 \mathrm{~m}$ beneath the water surface (Broda et al. 2015). Dating back to the tenth to twelfth centuries, the oak pile contained both sapwood and heartwood. Sapwood (20 to 30-mm thick) was characterised by a light, beige-greyish colour and a soft, disintegrated, spongy structure. Calculated on the basis of conventional wood density (Broda and Mazela 2017), loss of wood substance (LWS) for this part was 78\%, which confirms its high
Fig. 1 A map of the Ostrów Lednicki Lake with the location of the "Poznań" bridge (Kola and Wilke 2000)

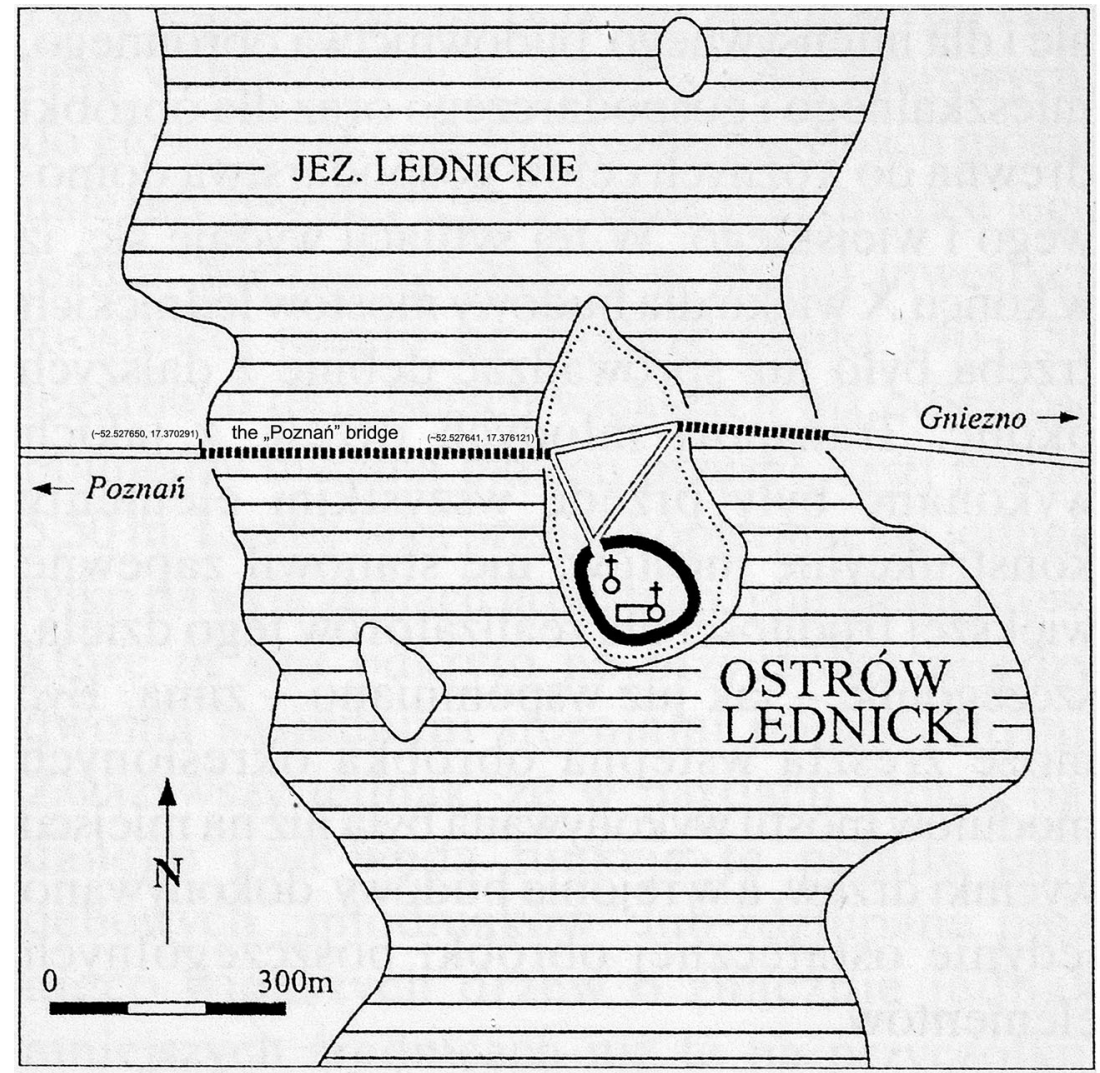


degradation level. By contrast, oak heartwood was dark brownish to almost black in colour, with a very firm and hard texture. This part of the wood was preserved very well (Table 1), especially the inner part which remained almost unchanged physically and its structure can be compared to contemporary wood.

The archaeological waterlogged oak pile was cut into 1$\mathrm{cm}$-thick slices. The slices were subdivided into four zones, differing in the level of wood degradation: sapwood (S) and heartwood: outer (H1), middle (H2) and inner (H3) (Fig. 2). Small square samples $(20 \times 20 \times 10 \mathrm{~mm}$, radial $\times$ tangential $\times$ longitudinal direction) were cut out from each zone. Additionally, contemporary oak ( $Q$. robur) wood from the Wielkopolska Region was examined.

\section{Methods}

\section{Sample preparation}

Due to the limited availability of archaeological wood, five samples from each zone were used for the analysis. All waterlogged wood samples were freeze-dried using a Lyovac lyophiliser GT2e (Steris, Germany) for $24 \mathrm{~h}$ (as well as dry contemporary wood samples). Samples from each zone were milled together on the laboratory cutting mill (MF 10 basic, IKA) to obtain the homogenised powdered mixture. Then $0.500 \pm 0.001$-g samples were weighed out and poured with $10 \mathrm{ml}$ of $70 \%$ nitric acid (Sigma-Aldrich, USA) in 50-ml PTFE containers. The samples were allowed to stay overnight for slow mineralisation. Then the samples were mineralised in a microwave oven (Mars Xpress 5, CEMUSA) using a modified EPA 3051 method (Frankowski et al. 2013).

The Sigma-Aldrich (USA) periodic table mix 1 for ICP containing $10 \mathrm{mg} \mathrm{L}^{-1}$ : $\mathrm{Al}$, As, $\mathrm{Ba}, \mathrm{Be}, \mathrm{Bi}, \mathrm{B}, \mathrm{Ca}, \mathrm{Cd}, \mathrm{Cs}, \mathrm{Cr}, \mathrm{Co}, \mathrm{Cu}$, $\mathrm{Ga}, \mathrm{In}, \mathrm{Fe}, \mathrm{Pb}, \mathrm{Li}, \mathrm{Mg}, \mathrm{Mn}, \mathrm{Ni}, \mathrm{P}, \mathrm{K}, \mathrm{Rb}, \mathrm{Se}, \mathrm{Si}, \mathrm{Ag}, \mathrm{Na}, \mathrm{Sr}, \mathrm{S}, \mathrm{Te}$, $\mathrm{Tl}, \mathrm{V}$ and $\mathrm{Zn}$ in $10 \%$ nitric acid (comprising HF traces) was used for calibration ICP-OES. In order to preserve the standard/sample conditions, the matrix match method was used.

\section{Instrumentation}

The inductively coupled plasma optical emission spectrometer (ICP-OES) ICPE-9820 (Shimadzu, Japan) with mini-torch was used for qualitative and quantitative detection of selected elements in waterlogged and contemporary oak wood

Table 1 Loss of wood substance of archaeological waterlogged piles

\begin{tabular}{lllll}
\hline & \multicolumn{4}{l}{ Waterlogged oak wood } \\
\cline { 2 - 5 } & $\mathrm{S}$ & $\mathrm{H} 1$ & $\mathrm{H} 2$ & $\mathrm{H} 3$ \\
\hline LWS [\%] & 78.0 & 13.8 & 6.0 & 1.0 \\
\hline
\end{tabular}

$S$ sapwood, $H 1$ outer heartwood, $H 2$ intermediate heartwood, $H 3$ inner heartwood

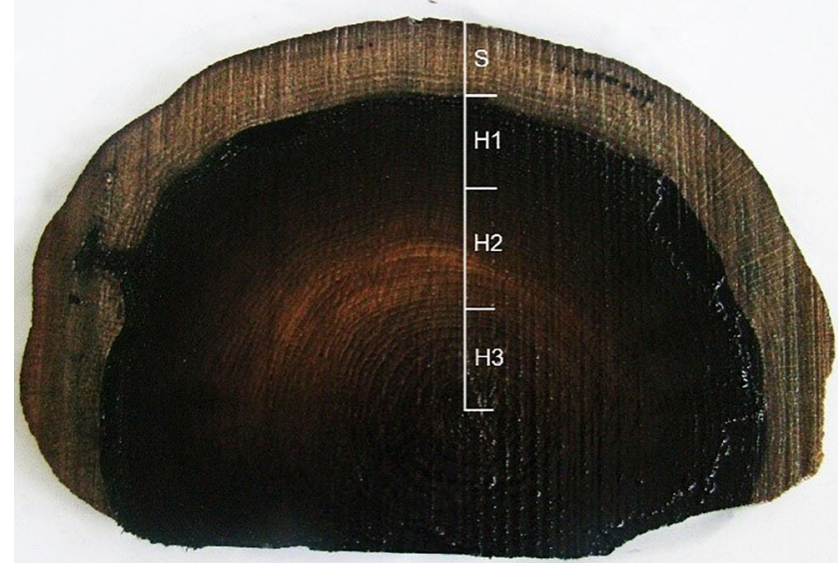

Fig. 2 The cross-section of waterlogged archaeological oak wood divided into four zones: $\mathrm{S}$ sapwood, $\mathrm{H} 1$ outer heartwood, $\mathrm{H} 2$ middle heartwood and $\mathrm{H} 3$ inner heartwood

samples. Table 2 presents basic operating conditions of the ICPE 9820. It should be underlined that spectrometer working with mini-torch consumes in total $11.3 \mathrm{~L} \mathrm{~min}^{-1}$ of $\mathrm{Ar}$, with the possibility to reduce the plasma argon to $7.0 \mathrm{~L} \mathrm{~min}^{-1}$ without loss of basic analytical parameters (Zioła-Frankowska and Frankowski 2017). This method allows to reduce cost (low Ar consumption) and time (simultaneous vacuum

Table 2 Operating conditions in Shimadzu ICPE-9820 spectrometer for analysis of wood samples

\begin{tabular}{|c|c|c|}
\hline \multicolumn{2}{|l|}{ Parameter } & Value \\
\hline \multicolumn{2}{|c|}{ Radio frequency power generator } & $1.2 \mathrm{~kW}$ \\
\hline \multicolumn{2}{|c|}{ Gas type } & Argon \\
\hline \multicolumn{2}{|c|}{ Plasma gas flow rate } & $10.0 \mathrm{~L} \mathrm{~min}^{-1}$ \\
\hline \multicolumn{2}{|c|}{ Auxiliary gas flow rate } & $0.6 \mathrm{~L} \mathrm{~min}^{-1}$ \\
\hline \multicolumn{2}{|c|}{ Nebulization gas flow rate } & $0.7 \mathrm{~L} \mathrm{~min}^{-1}$ \\
\hline \multicolumn{2}{|c|}{ Plasma view } & $\begin{array}{l}\text { Vertical torch, axial/radial } \\
\text { view }\end{array}$ \\
\hline \multicolumn{2}{|l|}{ Torch } & Mini-torch (quartz) \\
\hline \multicolumn{2}{|l|}{ Nebulizer } & Burgener NX-175 \\
\hline \multicolumn{2}{|l|}{ Chamber } & Cyclone (glass) \\
\hline \multicolumn{2}{|l|}{ Drain } & Gravity fed \\
\hline \multicolumn{2}{|l|}{ Injector tube } & Quartz (1.2 mm i.d.) \\
\hline \multicolumn{2}{|c|}{ Background correction } & 2-points \\
\hline \multicolumn{2}{|c|}{ Number of replicates } & 3 \\
\hline \multicolumn{2}{|c|}{ Exposure time } & $20 \mathrm{~s}$ \\
\hline \multicolumn{2}{|c|}{ Plasma viewing conditions } & $\begin{array}{l}\text { Axial view_all elements } \\
\text { Radial view_Ca and Mg }\end{array}$ \\
\hline \multicolumn{2}{|c|}{ Sample uptake rate } & $1 \mathrm{ml} \mathrm{min}^{-1}$ \\
\hline \multirow[t]{3}{*}{ Spectrometer } & Echelle optics & $\begin{array}{l}\text { Range of wavelength } 167 \text { to } \\
800 \mathrm{~nm}\end{array}$ \\
\hline & Resolution & $\leq 0.005$ at $200 \mathrm{~nm}$ \\
\hline & $\begin{array}{l}\text { Atmospheric } \\
\text { removal system }\end{array}$ & Rotary vacuum pump $\leq 10 \mathrm{~Pa}$ \\
\hline
\end{tabular}


spectrometer) of analysis and can be applied for routine analysis of samples with different matrix.

The SRM 1515 (National Institute of Standards and Technology, USA) certified reference material was used to check the reliability of the ICP-OES measurement. The results obtained for the certified reference material are presented in Table 3 as well as the spectral lines for each element.

\section{Results and discussion}

The content of elements mentioned in the previous section was determined in archaeological and contemporary oak wood samples. The results expressed as microgram per gram are presented in tables below. $\mathrm{Co}, \mathrm{Cr}, \mathrm{Li}, \mathrm{Mo}$, Ti and $\mathrm{V}$ content were also determined but were below the limit of detection of the analytical technique.

In waterlogged wood, the highest concentrations were observed for $\mathrm{Ca}, \mathrm{Fe}, \mathrm{Mg}$ and $\mathrm{P}$ (Table 4). Particularly high

Table 3 The wavelengths used for element contents determination and the values obtained for SRM 1515 by the ICP-OES analytical technique

\begin{tabular}{|c|c|c|c|c|}
\hline Element & $\begin{array}{l}\text { Wavelength } \\
{[\mathrm{nm}]}\end{array}$ & $\begin{array}{l}\text { LOD } \\
{\left[\mu \mathrm{g} \mathrm{L}^{-1}\right]}\end{array}$ & $\begin{array}{l}\text { Values obtained } \\
\text { for SRM } 1515 \text { by } \\
\text { the ICP-OES } \\
\text { analytical } \\
\text { technique }\end{array}$ & $\begin{array}{l}\text { Certified } \\
\text { value } \\
(\mathrm{SRM} 1515) \\
{\left[\mu \mathrm{g} \mathrm{g}^{-1}\right]}\end{array}$ \\
\hline $\mathrm{Al}$ & 167.081 & 15.9 & $291 \pm 10$ & $286 \pm 9$ \\
\hline B & 249.773 & 0.69 & $26 \pm 2$ & $27 \pm 2$ \\
\hline $\mathrm{Ba}$ & 455.403 & 0.17 & $48 \pm 1$ & $49 \pm 2$ \\
\hline $\mathrm{Ca}(\%)$ & 396.847 & 0.78 & $1.518 \pm 0.011$ & $1.526 \pm 0.015$ \\
\hline $\mathrm{Cd}$ & 226.502 & 0.30 & - & - \\
\hline Co & 228.616 & 0.49 & - & - \\
\hline $\mathrm{Cr}$ & 205.552 & 0.42 & - & - \\
\hline $\mathrm{Cu}$ & 324.754 & 0.96 & $5.50 \pm 0.22$ & $5.64 \pm 0.24$ \\
\hline $\mathrm{Fe}$ & 259.940 & 0.11 & - & - \\
\hline $\mathrm{K}(\%)$ & 766.490 & 2.29 & $1.65 \pm 0.04$ & $1.61 \pm 0.02$ \\
\hline $\mathrm{Li}$ & 670.784 & 0.09 & - & - \\
\hline $\operatorname{Mg}(\%)$ & 279.553 & 0.95 & $0.270 \pm 0.006$ & $0.271 \pm 0.008$ \\
\hline Mn & 257.610 & 0.04 & $55 \pm 1$ & $54 \pm 3$ \\
\hline Mo & 202.030 & 0.87 & $0.090 \pm 0.011$ & $0.094 \pm 0.013$ \\
\hline $\mathrm{Na}$ & 588.995 & 3.10 & $25.0 \pm 1.1$ & $24.4 \pm 1.2$ \\
\hline $\mathrm{Ni}$ & 231.604 & 0.58 & $0.89 \pm 0.10$ & $0.91 \pm 0.12$ \\
\hline $\mathrm{P}$ & 177.499 & 21.1 & - & - \\
\hline $\mathrm{Pb}$ & 216.999 & 3.18 & $0.462 \pm 0.032$ & $0.470 \pm 0.024$ \\
\hline $\mathrm{Sb}$ & 206.833 & 4.48 & - & - \\
\hline $\mathrm{Si}$ & 251.611 & 0.24 & - & - \\
\hline $\mathrm{Ti}$ & 334.941 & 0.33 & - & - \\
\hline V & 292.402 & 0.29 & $0.27 \pm 0.02$ & $0.26 \pm 0.03$ \\
\hline $\mathrm{Zn}$ & 213.856 & 0.33 & $12.7 \pm 0.2$ & $12.5 \pm 0.3$ \\
\hline
\end{tabular}

Table $4 \mathrm{Ca}, \mathrm{Fe}, \mathrm{Mg}$ and $\mathrm{P}$ content in oak wood

\begin{tabular}{lllll}
\hline Sample & \multicolumn{4}{l}{ Element content $\left[\mu \mathrm{g} \mathrm{g}^{-1}\right]$} \\
\cline { 2 - 5 } & $\mathrm{Ca}$ & $\mathrm{Fe}$ & $\mathrm{Mg}$ & $\mathrm{P}$ \\
\hline $\mathrm{S}$ & $6255 \pm 51$ & $3820 \pm 35$ & $280.5 \pm 3.3$ & $420.5 \pm 7.5$ \\
$\mathrm{H} 1$ & $5672 \pm 43$ & $4351 \pm 45$ & $268.5 \pm 3.7$ & $288.4 \pm 5.2$ \\
$\mathrm{H} 2$ & $6223 \pm 55$ & $3180 \pm 30$ & $318.5 \pm 4.2$ & $333.4 \pm 6.6$ \\
$\mathrm{H} 3$ & $4756 \pm 32$ & $1583 \pm 12$ & $194.2 \pm 2.0$ & $18.79 \pm 0.42$ \\
$\mathrm{CO}$ & $393.3 \pm 3.6$ & $2.504 \pm 0.178$ & $<\mathrm{LOD}$ & $13.69 \pm 0.35$ \\
\hline
\end{tabular}

$S$ archaeological oak sapwood, $H 1-H 3$ archaeological oak heartwood (outer, middle and inner, respectively), $\mathrm{CO}$ contemporary oak

content was observed for $\mathrm{Ca}$ ions ranging between $4756 \mu \mathrm{g} \mathrm{g}^{-1}$ for oak inner heartwood and $6255 \mu \mathrm{g} \mathrm{g}^{-1}$ for oak sapwood, which was about 12-16 times higher than in contemporary oak wood. Such high accumulation of this element in waterlogged wood tissue results from the specific conditions of the bottom of the Lednica Lake, the excavation site of the wooden pile. The lakebed is covered by a layer of slurry mud which is an early stage of a newly formed calcareous gyttja, overlying a sandy detritus-calcareous gyttja, containing a large number of mollusc shells (Kola and Wilke 2000). Calcium carbonate content in sediments of this type ranged between 25 and 50\% (Tobolski 1991).

Quite a high concentration of iron was also observed in waterlogged oak wood samples, varying from $1583 \mu \mathrm{g} \mathrm{g}^{-1}$ for $\mathrm{H} 3$ to $4351 \mu \mathrm{g} \mathrm{g}^{-1}$ for H1. It can be explained by the presence of a greater number of iron compounds in the burial environment (water and sediments) resulting from an enormous number of corroded medieval weapons found in the lake, especially within the area of the remains of the "Poznań" bridge (Kola and Wilke 2014). Moreover, the oak wood is especially susceptible to iron accumulation due to the high concentration of tannins. Tannins react with iron forming stable chemical compounds, which turns natural wood colour into dark brownish to almost black (it can be observed in the cross-section of an oak pile - see Fig. 2). Similar concentrations of iron were determined by the X-ray photoelectron spectroscopy in wooden elements of the Mary Rose warship, ranging from below $1000 \mu \mathrm{g} \mathrm{g}^{-1}$ in light-coloured wood to over $7000 \mu \mathrm{g} \mathrm{g}^{-1}$ in "black oak" (Sandström et al. 2005). Coming from corroding bolts, nails and other objects of mild steel present in oak construction of the ship, together with sulphur compounds they caused chemical wood degradation and probably also contributed to incremental degradation of PEG polymers used then for ship conservation (Sandström et al. 2005). Contemporary oak wood contained only $2.504 \mu \mathrm{g} \mathrm{g}^{-1}$ of iron ions.

Concentrations of two further nutrient elements, $\mathrm{Mg}$ and $\mathrm{P}$, were at a similar level in the outer and middle parts of waterlogged oak wood, ranging between 270 and $420 \mu \mathrm{g} \mathrm{g}^{-1}$. The inner, almost non-degraded part of wood contained a smaller 
amount of those elements. In case of $\mathrm{Mg}$ content, it was about $194.2 \mu \mathrm{g} \mathrm{g}^{-1}$, while in contemporary wood it was below the limit of detection. P content in the stem part was $18.79 \mu \mathrm{g} \mathrm{g}^{-1}$ and was comparable to its amount determined in contemporary wood (13.69 $\left.\mu \mathrm{g} \mathrm{g}^{-1}\right)$. Magnesium compounds in lake water and sediments mainly come from plant putrefaction. Mineral compounds of surrounded soils can also be a source of this element. By contrast, the phosphorus content has its roots primarily in intensification of agricultural production and, more precisely, in the intensive phosphorus fertilisation of encompassing cultivated lands. This element plays a crucial role in the eutrophication of inland waters (Reddy et al. 1999).

Five heavy metals content: cadmium $(\mathrm{Cd})$, copper $(\mathrm{Cu})$, manganese $(\mathrm{Mn})$, lead $(\mathrm{Pb})$ and zinc $(\mathrm{Zn})$ in oak wood was also determined. The highest concentration was recorded for $\mathrm{Mn}$ (34.01-59.28 $\mu \mathrm{g} \mathrm{g}^{-1}$ ) and $\mathrm{Pb}\left(4.022-9.713 \mu \mathrm{g} \mathrm{g}^{-1}\right)$. $\mathrm{Zn}$ and $\mathrm{Cu}$ were at a quite similar level about $1.116-7512 \mathrm{\mu g} \mathrm{g}^{-1}$ with the exception of sapwood part where higher concentrations of elements were observed: $5.038 \mu \mathrm{gg}^{-1}$ ofCu and $14.97 \mu \mathrm{g} \mathrm{g}^{-1}$ of $\mathrm{Zn}$. Lower concentration was found for $\mathrm{Cd}-$ about $0.2-0.6 \mu \mathrm{g}$ $\mathrm{g}^{-1}$. Heavy metals are introduced into the environment as a result of natural processes occurring in nature but also due to human activity, mainly industrial development. The presence of agricultural surroundings of the Lednica Lake protected it from pollution with heavy metals, which is visible in their low concentration in water (Table 5). The increased content of heavy metals in sediments (Table 5) is characteristic for lakes in northern Poland. It can be explained mainly by the presence of numerous mollusc remains at the bottom of the lake, forming calcareous gyttja. This kind of organism can absorb metals from water and accumulate them in their tissues, enriching the lake sediments with these elements (Baršyte Lovejoy 1999). From there, over the centuries, thanks to microbial activity, they diffused into water and then into wood tissue of the construction elements of the bridge, present in the mud at the bottom of the lake (Wood 1987).

Concentrations of other measured elements in waterlogged and contemporary oak wood are shown in Table 6. The highest concentration of potassium was observed in contemporary wood. This is a normal trait. Potassium plays a very important role in many metabolic processes and it is one of the most common elements in fresh wood (Kollman and Côté 1968). A relatively high potassium content in waterlogged wood can be explained by high accumulation of this element in lake sediments. The Lednica Lake is surrounded by farmland. Potassium, a very common component of fertilisers, is considered an indicator of the intensity of agricultural use of the catchment. Potassium content in sediments of similar lakes in the Masurian Lake District was 1.01 to $1.84 \mathrm{~g} \mathrm{~kg}^{-1}$ (Rafałowska and Sobczyńska-Wójcik 2014). Comparable results were obtained for sediments of the Masurian lakes surrounded by farmland and forest, where potassium content was between 0.66 and $1.31 \mathrm{~g} \mathrm{~kg}^{-1}$ (Szyperek 2005). In case of waterlogged wood, the highest content was observed for $\mathrm{Si}$, ranging from $59.45 \mu \mathrm{g} \mathrm{g}^{-1}$ in sapwood to $147.1 \mu \mathrm{g} \mathrm{g}^{-1}$ in heartwood. Only small concentrations of $\mathrm{Al}, \mathrm{B}, \mathrm{Ba} \mathrm{Na}, \mathrm{Ni}$ and $\mathrm{Sb}$ were observed in both waterlogged and contemporary oak wood.

The results of the ICP-OES analysis were standardised to visualise variability in the content of elements between different archaeological wood zones and contemporary wood, and the results for the whole data set are presented in Fig. 3. The Statistica 12.5 data analysis software system was used for data standardisation, the factor analysis and the principal component analysis (PCA) analyses (Stat Soft, Inc.). For archaeological waterlogged wood, a correlation between changes of elemental concentration and the degree of wood degradation (or loss of wood substance - see Table 1) in the respective wood
Table $5 \mathrm{Cd}, \mathrm{Cu}, \mathrm{Mn}, \mathrm{Pb}$ and $\mathrm{Zn}$ concentration in oak wood and water and sediments of the Lednica Lake

\begin{tabular}{|c|c|c|c|c|c|}
\hline \multirow[t]{2}{*}{ Sample } & \multicolumn{5}{|c|}{ Element content $\left[\mu \mathrm{g} \mathrm{g}^{-1}\right]$} \\
\hline & $\mathrm{Cd}$ & $\mathrm{Cu}$ & $\mathrm{Mn}$ & $\mathrm{Pb}$ & $\mathrm{Zn}$ \\
\hline S & $0.565 \pm 0.006$ & $5.038 \pm 0.069$ & $34.01 \pm 0.29$ & $8.399 \pm 0.122$ & $14.97 \pm 0.02$ \\
\hline H1 & $0.598 \pm 0.008$ & $1.393 \pm 0.014$ & $59.28 \pm 0.84$ & $9.713 \pm 0.143$ & $2.751 \pm 0.003$ \\
\hline $\mathrm{H} 2$ & $0.371 \pm 0.004$ & $1.162 \pm 0.011$ & $57.71 \pm 0.72$ & $8.138 \pm 0.111$ & $2.292 \pm 0.003$ \\
\hline $\mathrm{H} 3$ & $0.171 \pm 0.002$ & $1.223 \pm 0.011$ & $39.21 \pm 0.51$ & $4.022 \pm 0.092$ & $1.116 \pm 0.002$ \\
\hline $\mathrm{CO}$ & $<\mathrm{LOD}$ & $1.501 \pm 0.014$ & $71.43 \pm 0.92$ & $0.218 \pm 0.007$ & $0.429 \pm 0.003$ \\
\hline Water $\left[\mu \mathrm{g} \mathrm{ml}^{-1} 1\right]^{\mathrm{a}}$ & n.a. & $0.027 \pm 0.002$ & $0.056 \pm 0.006$ & $<\mathrm{LOD}$ & $0.056 \pm 0.001$ \\
\hline Sediment $\left[\mu \mathrm{g} \mathrm{g}^{-1}\right]$ & $1.58^{\mathrm{b}}$ & $38.89^{\mathrm{a}}$ & $103.42^{\mathrm{a}}$ & $71.5^{\mathrm{b}}$ & $147.59^{\mathrm{a}}$ \\
\hline
\end{tabular}

$S$ archaeological oak sapwood, $H 1-H 3$ archaeological oak heartwood (outer, middle and inner, respectively), $C O$ contemporary oak, n.a. not analysed

${ }^{\text {a }}$ Rybak et al. 2013

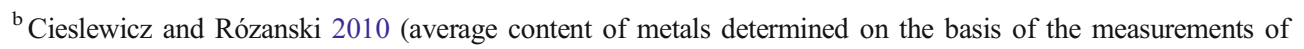
sediments from 13 lakes of northern Poland) 
Table 6 Concentration of Al, B, Ba, K, Na, Ni, Sb and $\mathrm{Si}$ in oak wood and water and sediments of the Lednica Lake

\begin{tabular}{|c|c|c|c|c|c|c|c|c|}
\hline \multirow[t]{2}{*}{ Sample } & \multicolumn{8}{|c|}{ Element content $\left[\mu \mathrm{g} \mathrm{g}^{-1}\right]$} \\
\hline & $\mathrm{Al}$ & $\mathrm{B}$ & $\mathrm{Ba}$ & $\mathrm{K}$ & $\mathrm{Na}$ & $\mathrm{Ni}$ & $\mathrm{Sb}$ & $\mathrm{Si}$ \\
\hline S & $11.43 \pm 0.13$ & $19.38 \pm 0.33$ & $15.69 \pm 0.11$ & $64.25 \pm 0.11$ & $24.79 \pm 0.32$ & $0.921 \pm 0.011$ & $3.138 \pm 0.044$ & $59.45 \pm 0.78$ \\
\hline H1 & $6.182 \pm 0.091$ & $23.51 \pm 0.38$ & $18.42 \pm 0.15$ & $40.05 \pm 0.08$ & $12.01 \pm 0.23$ & $0.911 \pm 0.015$ & $1.829 \pm 0.022$ & $147.1 \pm 2.28$ \\
\hline $\mathrm{H} 2$ & $3.633 \pm 0.053$ & $15.37 \pm 0.24$ & $7.895 \pm 0.07$ & $89.79 \pm 0.15$ & $12.24 \pm 0.21$ & $0.731 \pm 0.009$ & $2.681 \pm 0.37$ & $125.1 \pm 1.79$ \\
\hline $\mathrm{H} 3$ & $2.015 \pm 0.032$ & $11.01 \pm 0.19$ & $14.96 \pm 0.11$ & $33.36 \pm 0.08$ & $33.16 \pm 0.36$ & $0.398 \pm 0.005$ & $0.145 \pm 0.002$ & $130.7 \pm 1.87$ \\
\hline $\mathrm{CO}$ & $1.163 \pm 0.022$ & $3.416 \pm 0.044$ & $13.32 \pm 0.12$ & $500.4 \pm 6.2$ & $3.464 \pm 0.49$ & $0.083 \pm 0.001$ & $0.703 \pm 0.009$ & $70.27 \pm 0.92$ \\
\hline
\end{tabular}

$S$ archaeological oak sapwood, $H 1-H 3$ archaeological oak heartwood (outer, middle and inner, respectively), $C O$ contemporary oak

zones (S, H1-H3) was observed, which is marked with an arrow in Fig. 3. In most cases, the concentration of metals increases as the loss of wood substances rises from the core outward. Chemical compounds usually undergo deposition to bottom sediments. Wooden piles, dipped in sediments, slowly absorb the elements from the environment and accumulate them in wood tissue. The higher the degree of wood degradation, the less dense and more porous is the wood tissue, and the easier the penetration of metal ions. Oak wood is characterised by high density of about $710-900 \mathrm{~kg} \mathrm{~m}^{-3}$ in the dry state and is generally hard to impregnate. The most degraded, sponge-like sapwood zone is the most accessible for accumulation of ions, while the almost non-degraded inner heartwood part retains properties of fresh wood and remains low permeable, which was visible in the results obtained.

In case of contemporary wood, a variation in metal content was observed in comparison with waterlogged wood. In general, content of minerals in waterlogged wood considerably exceeds the average percentage of these elements in contemporary wood, which is associated with the mineralisation process frequently observed for archaeological wood excavated both from the ground and water reservoirs (Hoffmann 1982; Grattan and Mathias 1986). The exceptions are K and Mn contents which were significantly higher in contemporary wood. This could be explained by their leaching from waterlogged wood and then the usage of those minerals as nutrients by water plants and algae. Potassium is a very important element for plant cells. It is an activator of more than 50 enzymes and thus actively participates in the processes of respiration and photosynthesis. It also regulates water economy and supports cell growth. Together with calcium and magnesium, it is one of the most common elements in ashes from wood (Kollman and Côté 1968). Manganese also plays a very important metabolic function in plants. Its concentration in fresh wood can vary over a broad range, depending on the species, age and part of tree as well as on the manganese concentration in soil (Kabata-Pendias and Pendias 1999).

The principal component analysis was performed for the whole data set obtained to display similarities between wood zones and to compare archaeological waterlogged wood with
Fig. 3 The standardised results for the data set of the ICP-OES analysis for different zones of waterlogged wood (S sapwood, $\mathrm{H} 1-\mathrm{H} 3$ heartwood) and contemporary oak $(\mathrm{CO})$ wood

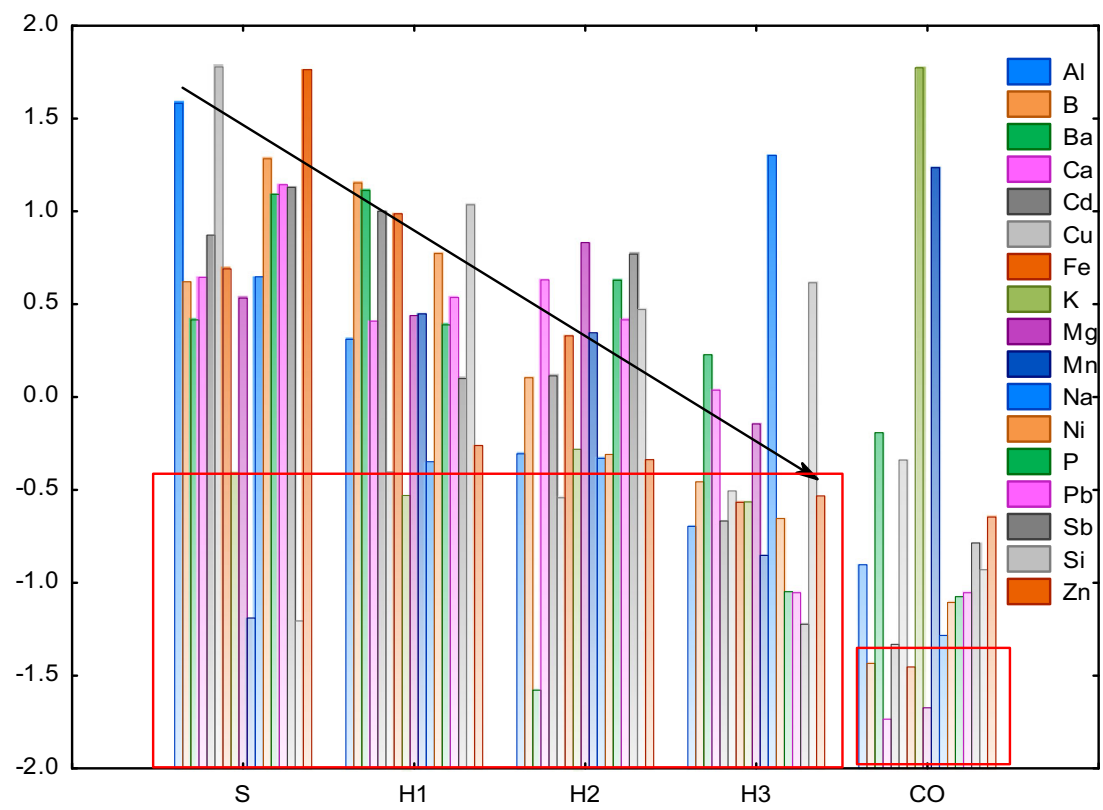


Fig. 4 The principal component analysis for the dataset of the ICPOES analysis for different zones of waterlogged wood (S sapwood, H1-H3 heartwood) and contemporary oak $(\mathrm{CO})$ wood

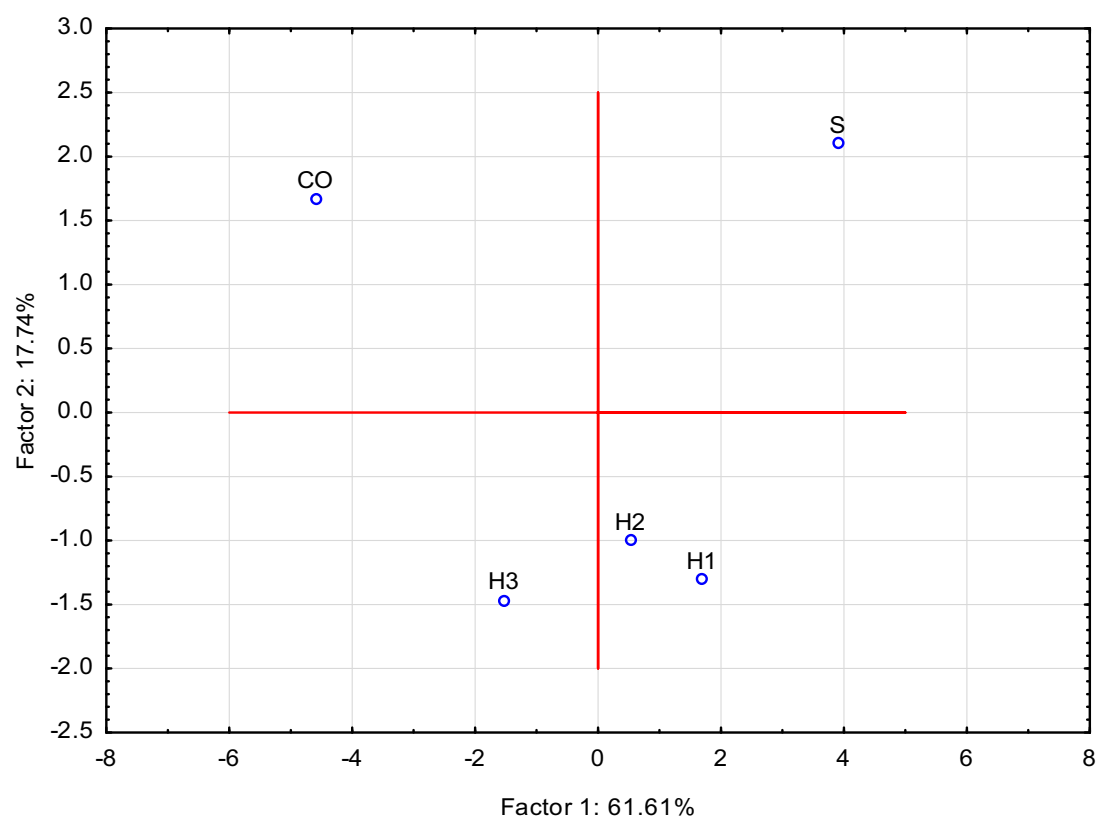

contemporary wood. The results of the analysis (Fig. 4) clearly illustrate the process of metal accumulation in waterlogged wood, especially in the heartwood zones H1-H3. However, based on the PCA, the deposition of metals in H1-H3 parts through the sapwood zone was confirmed. It should be underlined that adsorption of metals within the $\mathrm{S}$ zone and absorption into $\mathrm{H} 1-\mathrm{H} 3$ shows changes indicating the possible

Table 7 Matrix of factor loadings calculated on the basis of elements concentration in archaeological oak wood

\begin{tabular}{llll}
\hline Element & \multicolumn{2}{l}{$\begin{array}{l}\text { Factor loadings (varimax, normalised) } \\
\text { are }>0.700 \text { ) }\end{array}$} & (marked loads \\
\cline { 2 - 4 } & Factor 1 & Factor 2 & Factor 3 \\
\hline $\mathrm{Al}$ & 0.649 & 0.750 & 0.124 \\
$\mathrm{~B}$ & 0.999 & -0.020 & 0.013 \\
$\mathrm{Ba}$ & 0.524 & 0.184 & -0.831 \\
$\mathrm{Ca}$ & 0.519 & 0.271 & 0.810 \\
$\mathrm{Cd}$ & 0.968 & 0.191 & 0.161 \\
$\mathrm{Cu}$ & 0.315 & 0.944 & 0.095 \\
$\mathrm{Fe}$ & 0.963 & 0.029 & 0.265 \\
$\mathrm{~K}$ & -0.023 & 0.076 & 0.996 \\
$\mathrm{Mg}$ & 0.460 & -0.047 & 0.886 \\
$\mathrm{Mn}$ & 0.353 & -0.881 & 0.313 \\
$\mathrm{Na}$ & -0.629 & 0.542 & -0.556 \\
$\mathrm{Ni}$ & 0.844 & 0.534 & 0.002 \\
$\mathrm{P}$ & 0.675 & 0.346 & 0.651 \\
$\mathrm{~Pb}$ & 0.768 & 0.372 & 0.519 \\
$\mathrm{Sb}$ & 0.547 & 0.374 & 0.748 \\
$\mathrm{Si}$ & -0.072 & -0.962 & -0.261 \\
$\mathrm{Zn}$ & 0.365 & 0.915 & 0.166 \\
\hline & & &
\end{tabular}

"mechanism" of accumulation in waterlogged wood. Besides, a different relation for the $\mathrm{CO}$ sample was found, which is strongly connected with different external conditions that affect fresh wood (e.g. different content of metals in the environment).

In order to show the mechanism of absorption of the elements by wood, a comparison of the correlation between the elements evaluated for archaeological oak wood was made. To this end, the factor analysis was performed (Table 7). On the basis of the three factors, the analysis found only a negative correlation between $\mathrm{Ba}, \mathrm{Mn}$ and $\mathrm{Si}$ and a group of other metal ions. Elements such as $\mathrm{B}, \mathrm{Cd}, \mathrm{Fe}, \mathrm{Ni}$ and $\mathrm{Pb}$ are in the first group with the highest correlation (loads $>0.7$ ). These are elements derived from natural processes occurring in the environment, deposited in the lake mainly due to their run-off from the drainage basins. The second group consists of $\mathrm{Al}, \mathrm{Cu}$ and $\mathrm{Zn}$ coming from the natural weathering processes, the run-off from the surrounding fields and as a result of rainfall. In contrast, the third group contains the elements related mainly to agricultural activities on the catchment area, as $\mathrm{Ca}, \mathrm{K}$ and $\mathrm{Mg}$ are the common components of fertilisers.

\section{Conclusions}

The results of the presented research clearly show that archaeological oak wood excavated from the bottom of the Lednica Lake contained high quantities of metals. In general, waterlogged wood contained considerably higher concentrations of these elements than contemporary oak wood, which is associated with the mineralisation process of archaeological wood. Furthermore, variability in metal content was observed between waterlogged and contemporary wood. The highest 
concentrations of $\mathrm{Ca}, \mathrm{Fe}, \mathrm{Mg}$ and $\mathrm{P}$ elements (about 5700 and $3200 \mu \mathrm{g} \mathrm{g}^{-1}$ for $\mathrm{Ca}$ and $\mathrm{Fe}$, respectively, and about $260 \mu \mathrm{g} \mathrm{g}^{-1}$ for $\mathrm{Mg}$ and $\mathrm{P}$ ) were determined in archaeological wood samples while in contemporary oak wood the predominant concentrations of $\mathrm{K}$ (about $500 \mu \mathrm{g} \mathrm{g}^{-1}$ ), Ca (about $390 \mu \mathrm{g} \mathrm{g}^{-1}$ ), $\mathrm{Mn}$ and $\mathrm{Si}$ (about $70 \mu \mathrm{g} \mathrm{g}^{-1}$ ) were observed. The principal component analysis revealed the mechanism of accumulation of metals in waterlogged wood - the accumulation through the most degraded and porous sapwood zone to inner heartwood layers. In turn, the factor analysis allowed for identification of three groups of elements deposited in researched wood: metals derived from natural processes occurring in the environment, run-off to the lake from the drainage basins (like $\mathrm{B}, \mathrm{Cd}, \mathrm{Fe}, \mathrm{Ni}$ and $\mathrm{Pb}$ ), the elements from the natural weathering processes, leached out from the surrounding fields by rainfall (as $\mathrm{Al}, \mathrm{Cu}$ and $\mathrm{Zn}$ ) and metals related mainly to agricultural activities, as $\mathrm{Ca}, \mathrm{K}$ and $\mathrm{Mg}$. This analysis showed also only a negative correlation between $\mathrm{Ba}, \mathrm{Mn}$ and $\mathrm{Si}$ and a group of other metal ions.

On the basis of the results of this case study, it could be concluded that waterlogged wood acts as an adsorbent of elements from water and sediments. Therefore, high content of metal ions in such kind of wood may be expected. This can be an impediment in developing new formulations for conservation, while using this kind of wooden artefacts as an experimental material. Therefore, while planning to use new chemicals as conservation agents, the possible interactions between chemicals and metals must be taken into consideration.

Acknowledgments The authors would like to express their thanks to the Directorate of the Museum of the First Piasts at Lednica for sharing the historic archaeological waterlogged oak pile and to Dr. Krzysztof Radka for excavating it from the bottom of the lake.

The research was partially supported by the Polish Ministry of Science and Higher Education as a part of the "Cultural heritage - research into innovative solutions and methods for historic wood conservation" project within the National Programme for the Development of Humanities in 2016-2019 (Project No. 2bH 150037 83).

Open Access This article is distributed under the terms of the Creative Commons Attribution 4.0 International License (http:// creativecommons.org/licenses/by/4.0/), which permits unrestricted use, distribution, and reproduction in any medium, provided you give appropriate credit to the original author(s) and the source, provide a link to the Creative Commons license, and indicate if changes were made.

\section{References}

Almkvist G, Hocker E, Sahlstedt M (2013) Iron removal from waterlogged wood. Swedish University of Agricultural Sciences. SLU Repro, Uppsala

Baker AJ (1974) Degradation of wood by products of metal corrosion. USDA Forest Service research paper FPL-229

Bardet M, Gerbaud G, Giffard M, Doan C, Hediger S, Le Pape L (2009) ${ }^{13} \mathrm{C}$ high-resolution solid-state NMR for structural elucidation of archaeological woods. Prog Nucl Mag Res Sp 55:199-214
Baršyte Lovejoy D (1999) Heavy metal concentrations in water, sediments and mollusc tissues. Acta Zoologica Lituanica 9(2):12-20

Björdal CG (2012) Microbial degradation of waterlogged archaeological wood. J Cult Herit 13(3):S118-S122

Björdal CG, Nilsson T, Daniel G (1999) Microbial decay of waterlogged archaeological wood found in Sweden. Applicable to archaeology and conservation. Int Biodeter Biodegr 43(1-2):63-73

Blanchette RA (2010) Microbial degradation of wood from aquatic and terrestrial environments. In: Mitchell R, Mcnamara CJ (eds) Cultural heritage microbiology. Fundamental studies in conservation science. ASM press, Washington. DC, pp 179-218

Blanchette RA, Simpson E (1992) Soft rot and wood pseudomorphs in an ancient coffin (700 B.C.) from Tumulus MM at Gordion, Turkey. IAWA Bull B.S. 13:201-213

Blanchette RA, Cease KR, Abad AR, Koestler RJ, Simpson E, Sams GK (1991) An evaluation of different forms of deterioration found in archaeological wood. Int Biodeterior 28:3-22

Blanchette RA, Haight JE, Koestler RJ, Hatchfield PB, Arnold D (1994) Assessment of deterioration in archaeological wood from ancient Egypt. J Am Inst Conserv 33(1):55-70

Braovac S, Tamburini D, Łucejko JJ, McQueen C, Kutzke H, Colombini MP (2016) Chemical analyses of extremely degraded wood using analytical pyrolysis and inductively coupled plasma atomic emission spectroscopy. Microchem J 124:368-379

Broda M, Mazela B (2017) Application of methyltrimethoxysilane to increase dimensional stability of waterlogged wood. J Cult Herit 25:149-156

Broda M, Mazela B, Królikowska-Pataraja K, Hill CAS (2015) The use of FT-IR and computed tomography non-destructive technique for waterlogged wood characterisation. Wood Res Slovakia 5:707-722

Browning BL (1967) Methods of wood chemistry, vol Volumes I and II. Interscience Publishers, New York

Cieslewicz J, Rózanski S (2010) Metale ciężkie w osadach dennych jezior. Ochrona Środowiska i Zasobów Naturalnych 44:72-82

Florian MLE (1990) Scope and history of archaeological wood. In: Rowell RM, Barbour RJ (eds), Archaeological wood: properties, chemistry and preservation. American Chemical Society, Washington DC, no. 225. p 1-32

Fors Y, Sandström M (2006) Sulfur and iron in shipwrecks cause conservation concerns. Chem Soc Rev 35:399-415

Fors Y, Jalilehvand F, Risberg ED, Björdal C, Phillips E, Sandström M (2012) Sulfur and iron analyses of marine archaeological wood in shipwrecks from the Baltic Sea and Scandinavian waters. J Archaeol Sci 39(7):2521-2532

Frankowski M, Zioła-Frankowska A, Siepak J (2013) From soil to leaves-aluminum fractionation by single step extraction procedures in polluted and protected areas. J Environ Manage 127:1-9

Grattan D, Mathias C (1986) Analysis of waterlogged wood. The value of chemical analysis and other simple methods in evaluating condition. Somerset Levels Papers 12:6-12

Henry WP (2003) Non-enzymatic iron, manganese, and copper chemistry of potential importance in wood decay. In: Goodell B, Nicholas DD, Schultz TP (eds) Wood deterioration and preservation. American Chemical Society, Washington DC, pp 175-195

Hingston JA, Collins CD, Murphy RJ, Lester JN (2001) Leaching of chromated copper arsenate wood preservatives: a review. Environ Pollut 111(1):53-66

Hoffmann P (1982) Chemical wood analysis as a means to characterize archaeological wood. Proceedings of the ICOM Waterlogged Wood Working Group Conference, Ottawa 1981:73-83

Huisman DJ, Manders MR, KretschmarEI, Klaassen RKWM, LamersdorfN (2008) Burial conditions and wood degradation at archaeological sites in the Netherlands. Int Biodeter Biodegr 61(1):33-44

Kabata-Pendias A, Pendias H (1999) Biogeochemia pierwiastków śladowych. Wydawnictwo Naukowe PWN, Warszawa 
Keepax C (1975) Scanning electron microscopy of wood replaced by iron corrosion products. J Archaeol Sci 2:145-150

Kim YS, Singh AP, Nilsson T (1996) Bacteria as important degraders in waterlogged archaeological woods. Holzforschung 50:389-392

Kola A, Wilke G (2000) Mosty sprzed tysiąca lat. Archeologiczne badania podwodne przy rezydencji pierwszych Piastów na Ostrowie Lednickim. Wydawnictwo Naukowe Uniwersytetu Mikołaja Kopernika, Toruń

Kola A, Wilke G (Ed.) (2014) Wczesnośredniowieczne mosty przy Ostrowie Lednickim. Tom II: Mosty traktu poznańskiego (wyniki archeologicznych badań podwodnych prowadzonych w latach 1986-2003). Towarzystwo Autorów i Wydawców Prac Naukowych "Universitas", Kraków

Kollman FF, Côté WA (1968) Principles of wood science and technology, vol I. Springer-Verlag, Berlin

Łucejko JJ, Modugno F, Ribechini E, Tamburini D, Colombini MP (2015) Analytical instrumental techniques to study archaeological wood degradation. Appl Spectrosc Rev 50(7):584-625

Marian JE, Wissing A (1960) The chemical and mechanical deterioration of wood in contact with iron: part 2. Chemical decomposition. Svensk Pappersmassetidning 63:98-106

Obanda DN, Shupe TF, Barnes HM (2008) Reducing leaching of boronbased wood preservatives - a review of research. Bioresour Technol 99(15):7312-7322

Parameswaran N (1981) Micromorphology of spruce timber after longterm service in a potash store house. Holz Roh Werkst 39:149-156

Parameswaran N, Borgin K (1980) Micromorphological and analytical study of an ancient pinewood from Cyprus containing metallic copper. Holzforschung 34:185-190

Pizzo B, Pecoraro E, Alves A, Macchioni N, Rodrigues JC (2015) Quantitative evaluation by attenuated total reflectance infrared (ATR-FTIR) spectroscopy of the chemical composition of decayed wood preserved in waterlogged conditions. Talanta 131:14-20

Preston J, Smith AD, Schofield EJ, Chadwick AV, Jones MA, Watts JEM (2014) The effects of Mary Rose conservation treatment on iron oxidation processes and microbial communities contributing to acid production in marine archaeological timbers. PLoS One 9(2):1-8
Rafałowska M, Sobczyńska-Wójcik K (2014) Akumulacja materii w osadach dennych zatoki Pilwa (Jezioro Dobskie) pod wpływem intensywnej produkcji rolnej. Proc ECOpole 8(1):261-266

Reddy KR, Kadlec RH, Flaig E, Gale PM (1999) Phosphorus retention in streams and wetlands: a review. Crit Rev Env Sci Tec 29:83-146

Rybak A, Messyasz B, Pikosz M, Szendzina L, Łęska B (2013) Accumulation of heavy metals $(\mathrm{Co}, \mathrm{Cr}, \mathrm{Cu}, \mathrm{Mn}, \mathrm{Zn})$ in the freshwater alga Ulva type, sediments and water of the Wielkopolska region, Poland. Nauka Przyroda Technologie, Dział: Melioracje i Inżynieria Środowiska, 7(4):66 s.1-15

Salanti A, Zoia L, Tolppa EL, Giachi G, Orlandi M (2010) Characterization of waterlogged wood by NMR and GPC techniques. Microchem J 95(2):345-352

Sandström M, Jalilehvand F, Persson I, Gelius U, Frank P, Hall-Roth I (2002) Deterioration of the seventeenth-century warship Vasa by internal formation of sulphuric acid. Nature 415:893-897

Sandström M, Fors Y, Jalilehvand F, Damian E, Gelius U (2004) Analyses of sulfur and iron in marine-archaeological wood. In: Proceedings of the Ninth ICOM Group on Wet Organic Archaeological Materials Conference, Copenhagen p. 181-199

Sandström M, Jalilehvand F, Damian E, Fors Y, Gelius U, Jones M, Salomé M (2005) Sulfur accumulation in the timbers of King Henry VIII's warship Mary Rose: a pathway in the sulfur cycle of conservation concern. P Natl Acad Sci USA 102(40):14165-14170

Szyperek U (2005) Wpływ zagospodarowania zlewni na skład chemiczny osadów dennych oczek wodnych. Cz. I. Zawartość i akumulacja azotu, fosforu i potasu. J Elem 10(2):411-419

Tobolski K (1991) Dotychczasowy stan badań paleobotanicznych i biostratygraficznych Lednickiego Parku Krajobrazowego: Wstęp do paleoekologii Lednickiego Parku Krajobrazowo. Biblioteka Studiów Lednickich. Wydawnictwo Naukowe UAM, Poznań, p. 11-34

Wood JM (1987) Biological processes involved in the cycling of elements between soil or sediments and the aqueous environment. Hydrobiologia 149(1):31-42

Zioła-Frankowska A, Frankowski M (2017) Determination of selected metals in wines using inductively coupled plasma optical emission spectrometry with mini torch. Food Anal Methods 10(1):180-190 